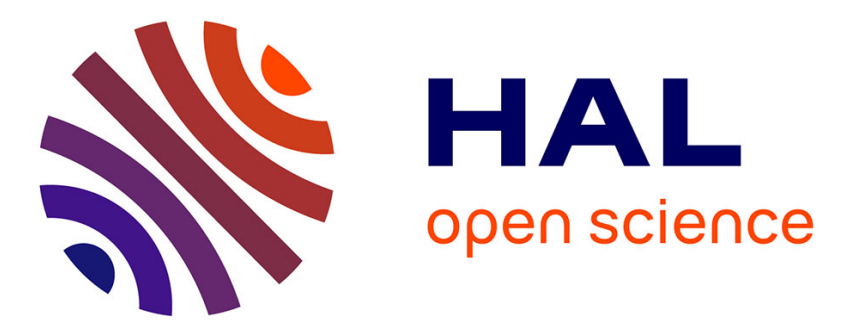

\title{
Performances of six eupelmid egg parasitoids from China on Japanese giant silkworm Caligula japonica with different host age regimes
}

Yong-Ming Chen, Xing-Ran Qu, Tian-Hao Li, Asim Iqbal, Xingeng Wang, Zhi-Yong Ren, Nicolas Desneux, Lian-Sheng Zang

\section{To cite this version:}

Yong-Ming Chen, Xing-Ran Qu, Tian-Hao Li, Asim Iqbal, Xingeng Wang, et al.. Performances of six eupelmid egg parasitoids from China on Japanese giant silkworm Caligula japonica with different host age regimes. Journal of Pest Science, 2021, 94 (2), pp.309-319. 10.1007/s10340-020-01271-1 . hal-03279613

\section{HAL Id: hal-03279613 \\ https://hal.inrae.fr/hal-03279613}

Submitted on 6 Jul 2021

HAL is a multi-disciplinary open access archive for the deposit and dissemination of scientific research documents, whether they are published or not. The documents may come from teaching and research institutions in France or abroad, or from public or private research centers.
L'archive ouverte pluridisciplinaire HAL, est destinée au dépôt et à la diffusion de documents scientifiques de niveau recherche, publiés ou non, émanant des établissements d'enseignement et de recherche français ou étrangers, des laboratoires publics ou privés.

\section{(c)(1)}

Distributed under a Creative Commons Attribution| 4.0 International License 


\title{
Performances of six eupelmid egg parasitoids from China on Japanese giant silkworm Caligula japonica with different host age regimes
}

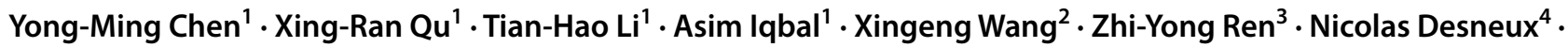 \\ Lian-Sheng Zang ${ }^{1}$ (1)
}

Received: 18 April 2020 / Revised: 7 August 2020 / Accepted: 10 August 2020 / Published online: 17 August 2020

(c) Springer-Verlag GmbH Germany, part of Springer Nature 2020

\begin{abstract}
The Japanese giant silkworm Caligula japonica Moore is an emerging defoliator pest of forest and fruit trees, causing severe economic losses in East Asia. To identify biological control agents for this pest, we comparatively evaluated six indigenous eupelmid egg parasitoids (Anastatus fulloi, A. gansuensis, A. japonicus, A. meilingensis, Mesocomys albitarsis and M. trabalae) from China, in terms of their performances (number of parasitized eggs, developmental time, offspring emergence and sex ratio) on $C$. japonica eggs of four different ages (0, 10, 20 and 30-d old). Results showed that all six parasitoids readily parasitized $C$. japonica eggs of all tested ages, but $A$. japonicus was the most efficient species based on the number of parasitized eggs, followed by M. albitarsis and M. trabalae, and the other three parasitoid species. All four Anastatus species parasitized more old than young eggs, while M. albitarsis did not show a strong host age preference and $M$. trabalae parasitized the oldest less than young eggs. For all host ages, developmental time was longest in A. gansuensis and shortest in M. albitarsis, offspring emergence was high (>90\%), and progeny was strongly female biased $(>70 \%)$ among all parasitoids except for A. gansuensis which produced all female progeny. Portions of A. japonicus offspring $(<13.1 \%)$ entered diapause as pre-pupae. Accordingly, A. japonicus, M. albitarsis and M. trabalae were identified as the most suitable agents against $C$. japonica. This information may also help improve rearing and field-release protocols, in terms of host age-related effects on these parasitoids.
\end{abstract}

Keywords Anastatus $\cdot$ Mesocomys $\cdot$ Host age preference $\cdot$ Host suitability $\cdot$ Biological control

\section{Key message}

Communicated by M. Traugott.

Lian-Sheng Zang

1sz0415@163.com

1 Jilin Engineering Research Center of Resource Insects Industrialization, Institute of Biological Control, Jilin Agricultural University, Changchun, China

2 United States Department of Agriculture, Agricultural Research Service, Beneficial Insects Introduction Research Unit, Newark, DE 19713, USA

3 Institute of Walnut, Longnan Economic Forest Research Institute, Wudu, China

4 Université Côte d'Azur, INRAE, CNRS, UMR ISA, 06000 Nice, France
- Caligula japonica is an emerging forest and fruit tree pest in East Asia

- Six indigenous eupelmid egg parasitoids in China were evaluated for their performances on C. japonica eggs of different ages

- All six parasitoids readily parasitized $C$. japonica eggs of different ages

- Anastatus japonicus, Mesocomys albitarsis and M. trabalae were identified as the most suitable agents against $C$. japonica eggs based on their overall performances 


\section{Introduction}

The Japanese giant silkworm (JGS) Caligula japonica Moore (Lepidoptera: Saturniidae) is a defoliator pest of forest and fruit trees in East Asia (Qiao et al. 2014; Abarenkov 2019; Nashiki 2019). In China, 38 plant species belonging to 30 genera in 20 families have been reported as hosts of this pest, including various important fruit trees such as walnut (Juglans regia L.), chestnut (Castanea mollissima Blume), ginkgo (Ginkgo biloba L.), plums (Prunus spp.), pears (Pyrus spp.), apple (Malus pumila Mill.) and sumac [Toxicodendron vernicifluum (Stokes)] (Yang et al. 2008a; Qiao et al. 2014). Since it was first reported in 2006 in Kangxian, Gansu Province (northwestern China), JGS has rapidly spread and emerged as a major pest of walnut trees. About 27,330 hectares of walnut trees were infested by JGS in 2011 in Kangxian alone, causing an estimated economic loss of $\$ 20$ million (Qiao et al. 2014). There is a high possibility of further outbreaks of this pest (Yang et al. 2008b; Qiao et al. 2014). In other regions in East Asia, JGS was also reported as a serious pest of deciduous forest and shade trees such as plums, chestnuts, camphor (Cinnamomum sp.) and birch (Betula maximowicziana Regel.) in Japan (Clausen 1927; Kawasaki and Sato 1985; Ohno et al. 2008).

Currently, control strategies against JGS rely on the application of broad-spectrum insecticides in China (Dong 2013). Unfortunately, insecticides are often not applied in a timely manner or applied repeatedly, leading to the development of pesticide resistance in the pest (Wang et al. 2012). Furthermore, pesticide applications could disrupt established IPM for other pests, increase chemical residues, negatively affect pollinators and other beneficial or non-target organisms, and cause harm to the environment and human health (Weisenburger 1993; Desneux et al. 2007; Qu et al. 2015). Although some entomopathogenic fungi, bacteria and viruses have been tested for the control of this pest, these pathogens yielded unsatisfactory results (Tetsu et al. 1974; Liu and Luo 2008). Under this scenario, it is urgently needed to develop effective but also environmentally friendly control strategies for this pest.

Biological control with insect parasitoids to control forest pests has been practiced from a long time (Fischbein and Corley 2015). Among insect natural enemies, egg parasitoids would be ideal agents for the control of insect pests as they kill host pests before the pests cause potential damage to host plants. Indeed, many egg parasitoids such as trichogrammatids have been widely massproduced and released for the control of Lepidopteran pests globally including China (Smith 1996; Mills 2010; Huang et al. 2020; Zang et al. 2021). For example, the egg parasitoid Anastatus japonicus Ashmead (Hymenoptera:
Eupelmidae) (later identified as A. fulloi Sheng \& Wang) has been mass-produced and released annually to control the litchi stink bug Tessaratoma papillosa Stål (Hemiptera: Tessaratomidae) in China since the late 1960s (Li et al. 2014). Recently, the egg parasitoids Trissolcus japonicus Ashmead (Hymenoptera: Scelionidae) and A. bifasciatus Geoffroy are considered as candidate biological control agents for inundative releases against the invasive brown marmorated stink bug Halyomorpha halys (Stål) (Hemiptera: Pentatomidae) in North America and Europe (Talamas et al. 2015; Stahl et al. 2018a, b; Abram et al. 2019). We surveyed indigenous egg parasitoids associated with JGS in walnut orchards in northwestern China in 2017 and 2018, and collected seven parasitoid species from parasitized JGS eggs, namely Anastatus fulloi Sheng \&Wang, A. gansuensis Chen \& Zang, A. japonicus, A. meilingensis Sheng \& Yu, Mesocomys albitarsis (Ashmead) and M. trabalae Yao, Yang \& Zhao (all Hymenoptera: Eupelmidae), and Aprostocetus brevipedicellus Yang and Cao (Hymenoptera: Eulophidae) species (Chen et al. 2020). Parasitism rates of JGS egg masses (individual eggs) ranged from $0.55 \%(0.01 \%)$ to $30.41 \%$ (3.59\%) in the fields (Chen et al. 2020). Among them, A. fulloi is a widely distributed and well-studied species as a biological control agent of various lepidopteran and pentatomid (Hemiptera) eggs ( $\mathrm{Li}$ et al. 2014). Mesocomys albitarsis was reported as a major egg parasitoid of JGS in Japan (Clausen 1927). All of them were newly reported on JGS in northwestern China, and A. gansuensis was a newly described species (Chen et al. 2019). This field survey indicated the potential of these locally occurring egg parasitoids for the biological control of JGS. Indigenous parasitoids have already adapted to local ecological conditions and if they can adapt to newly emerging or invading pests, they may be manipulated to suppress the pests through conservative and augmentative biological control (Yuan et al. 2012; Fischbein et al. 2019). One of such examples is the fall webworm moth Hyphantria cunea Drury (Lepidoptera: Erebidae), an exotic and invasive pest that has been successfully controlled by the indigenous pupal parasitoid Chouioia cunea Yang (Hymenoptera: Eulophidae) in China (Yang et al. 2006).

The production of natural enemies for use in biological control programs is often rather expensive, where the attempt to acquire a cost-effective production system is the main objective of many biological control programs (Watt et al. 2015). The Chinese oak silkworm Antheraea pernyi Guérin-Méneville (Lepidoptera: Saturniidae) has been considered as an ideal factitious host for the mass production of A. fulloi and Pseudanastatus albitarsis (=M. albitarsis) to control T. papillosa and Dendrolimus punctatus Walker (Lepidoptera: Lasiocampidae), respectively (Teng and Ni 1989; Li et al. 2014), because of its high parasitism rates, low rearing costs, and easy storage and transportation $(\mathrm{Li}$ 
et al. 2019; Iqbal et al. 2019). However, the suitability of $A$. pernyi eggs as a rearing host for other egg parasitoids has not yet be evaluated. This study aimed to identify the most suitable agents for biological control of JGS among six recently discovered indigenous eupelmid egg parasitoids: A. fulloi, A. gansuensis, A. japonicus, A. meilingensis, M. albitarsis and $M$. trabalae using $A$. pernyi egg as a factitious host. The eulophid A. brevipedicellus was not tested because of its low field parasitism on individual JGS eggs $(<1.1 \%)$ or egg masses $(<2.2 \%)$ during the field surveys (Chen et al. 2020). Specifically, we comparatively evaluated their relative performances on differently aged JGS eggs in terms of the number of parasitized eggs and offspring fitness. Augmentative or inundative release programs rely on not only selection of parasitoid species that preferentially attack target pests and are well adapted to the agroecosystem of the target pests, but also efficient mass-rearing systems to produce large numbers of high-quality parasitoids (Smith 1996). Age-related development changes in host, both physiological and morphological, can result in variable host quality and influence a parasitoid's host acceptance for oviposition and suitability for offspring (Nurindah et al. 1999; Li et al. 2014; Stahl et al. 2018a; Iqbal et al. 2019). This is particularly true for parasitoids attacking static developmental stages such as egg and pupa, as the quantity of resources available for the development of parasitoid progeny is determined at the time of parasitism (Vinson 1976; Pizzol et al. 2012; Zhang et al. 2014; Hou et al. 2018). Therefore, we also compared the effect of host age on the performances of these parasitoids. This information will help select suitable host age for the rearing or timing of field release of these parasitoids.

\section{Materials and methods}

\section{Parasitoids}

Laboratory colonies of the six eupelmid egg parasitoids (Anastatus fulloi, A. gansuensis, A. japonicus, A. meilingensis, Mesocomys albitarsis and M. trabalae) were established with adult wasps emerged from field-collected and parasitized JGS egg masses in walnut orchards in 2017 in Kangxian $\left(105-106^{\circ} \mathrm{E}, 32.9-33.7^{\circ} \mathrm{N}\right)$, northwestern China. Each species was identified based on the morphological characteristics as described by Gibson $(1995,1997,2011)$ and Gibson and Fusu (2016). All six species were further verified using voucher specimens as identified by Dr. Gibson in 2018. The cytochrome oxidase subunit I gene (COI) sequences of the four Anastatus species were also analyzed according to Hebert et al. (2003). All voucher specimens were deposited in the Institute of Biological Control collection, Jilin Agricultural University at Changchun, China (for additional information of these parasitoids, see Table 1).

Each parasitoid colony was initialed with 30 wasps and maintained on the factitious host $A$. pernyi eggs under controlled conditions $\left(25 \pm 1{ }^{\circ} \mathrm{C}, 70 \pm 5 \% \mathrm{RH}\right.$ and $\left.14 \mathrm{~L}: 10 \mathrm{D}\right)$. Mature A. pernyi moths were dissected to collect host eggs. The eggs were washed with distilled water and then air dried at normal room temperatures (Iqbal et al. 2019). Fifty eggs were glued on an egg card $(5.0 \times 1.0 \mathrm{~cm})$ and then exposed to individual females in small glass tubes $(10.0 \times 1.5 \mathrm{~cm})$ covered with fine mesh for $24 \mathrm{~h}$. Exposed eggs were held until the emergence of wasps. All six eupelmid egg parasitoids had been reared for five generations prior to their use in this study and rejuvenated every three to five generations by transferring them to rear on JGS eggs.

\section{Host insect}

JGS is a univoltine species; it lays eggs in the fall and overwinters as eggs in diapause from September to April of the following year in Kangxian, China (Yang et al. 2008b). JGS cocoons were collected in walnut orchards in Kangxian $\left(33^{\circ} 26^{\prime} 33.81^{\prime \prime} \mathrm{N}, 105^{\circ} 41^{\prime} 52.10^{\prime \prime} \mathrm{E}\right)$ during the middle of June 2019. Approximately, 300 cocoons were collected and placed in a plastic container $(25.5 \times 25.5 \times 5 \mathrm{~cm})$ inside an insect cage $(30 \times 30 \times 30 \mathrm{~cm})$. The cocoons were maintained in an open insectary so that they were exposed to similar field conditions $\left(23-29{ }^{\circ} \mathrm{C}, 60-85 \% \mathrm{RH}\right.$ and natural photoperiod) and emerged as field populations did from June
Table 1 Detailed information on six eupelmid egg parasitoid species tested in this study

\begin{tabular}{|c|c|c|c|}
\hline Parasitoid species & $\begin{array}{l}\text { GenBank acces- } \\
\text { sion number }\end{array}$ & Indigenous host ${ }^{\mathrm{a}}$ & Other hosts recorded (references) \\
\hline A. fulloi & MK604241 & Caligula japonica & Erthesina fullo (Sheng et al. 1997) \\
\hline A. gansuensis & MK373759 & C. japonica & \\
\hline A. japonicus & MK604240 & C. japonica & Antherea pernyi (Zhao et al. 2019) \\
\hline A. meilingensis & MK604242 & C. japonica & $\begin{array}{l}\text { Dendrolimus punctatus, D. kikuchii } \\
\text { (Sheng and Yu 1998) }\end{array}$ \\
\hline M. albitarsis & - & C. japonica & Dendrolimus spectabilis (Hirose 1964) \\
\hline M. trabalae & - & C. japonica & Trabala vishnou (Yao et al. 2009) \\
\hline
\end{tabular}

${ }^{\mathrm{a}}$ Host species from which the parasitoid was originally collected for this study (Chen et al. 2019, 2020) 
to September. Newly emerged adults were paired and kept in insect rearing cages $(50 \times 50 \times 50 \mathrm{~cm})$. The adults were monitored daily for oviposition, and newly laid eggs were collected and kept under the same conditions as described above until they reached required ages (see below) for experiments.

\section{Experimental setup}

Experiments were conducted under laboratory conditions $\left(25 \pm 1{ }^{\circ} \mathrm{C}, 70 \pm 5 \% \mathrm{RH}\right.$ and $\left.14 \mathrm{~L}: 10 \mathrm{D}\right)$. To determine the performance of each of the six egg parasitoids on differentaged JGS eggs, four different ages (0, 10, 20 and 30-d old) of JGS eggs were selected to cover a wide range of aged hosts that could be attacked by these parasitoids in the field. Because adult JGS females start oviposition in September in Kangxian, China, where monthly field temperatures vary from 8 to $28^{\circ} \mathrm{C}$ (mean $15.5^{\circ} \mathrm{C}$ ) in September and 2 to $21^{\circ} \mathrm{C}$ (mean $11.5^{\circ} \mathrm{C}$ ) in October based on weather data available at https://www.tianqi.com. Field temperatures drop dramatically after October $(\approx 30$-d old of early laid JGS eggs) when these parasitoids are likely no longer active in the field (Fang et al. 1995). Newly emerged adult wasps ( $<6 \mathrm{~h}$ old) were collected and held in a group of ten pairs (except for A. gansuensis, which produces by parthenogenesis) in a cylindrical and transparent plastic container $(9.0 \times 14.0 \mathrm{~cm}$, diameter $\times$ height) covered with fine mesh for $3 \mathrm{~d}$ to allow mating, with $30 \%$ honey solution provided as food for the parasitoids. All tests used 3-d old and mated female wasps. Our preliminary observations found that all the six parasitoids could not parasitize more than 30 eggs per female wasp per $24 \mathrm{~h}$, therefore, female wasps were individually exposed to 50 host eggs of $0,10,20$ or $30 \mathrm{~d}$-old in a no choice test (i.e., with unlimited access to hosts). The host eggs were glued on a strip-shaped egg card $(5.0 \times 1.0 \mathrm{~cm})$ and exposed to the parasitoid in a small glass tube $(10.0 \times 1.5 \mathrm{~cm})$ covered with fine mesh. The test procedures were similar for each parasitoid species at each tested host age.

A replicate was discarded if the wasp was found dead at the end of the 24-h exposure. Following the 24-h exposure, the wasps were removed, and all exposed eggs were checked daily for the emergence of wasps until no wasps emerged for a consecutive of $20 \mathrm{~d}$. Finally, all host eggs without a parasitoid emergence hole were dissected under a stereomicroscope to determine the fate of each egg, i.e., either dead and unparasitized or parasitized with a recognizable dead parasitoid larva, a dead or live parasitoid pupa or a developed but dead adult inside the host egg. Images (examples) were taken for these different scenarios using a Nikon camera and/or Keyence VHX-2000 digital microscope. There were 15 valid replicates for each parasitoid species and host age treatment.
For each treatment replicate, we calculated the number of parasitized eggs (=number of host eggs with a parasitoid emergence hole + number of host eggs containing a parasitoid larva, pupa or adult), percentage of offspring emergence (=number of host eggs with a parasitoid emergence hole $\times 100 /$ number of parasitized eggs), percentage of female progeny ( $=$ number of emerged and unemerged adult females $\times 100 /$ total number of emerged and unemerged adults) and developmental time (d) of individual wasps from the oviposition to adult emergence. Also, the percentages of offspring died as larvae, undeveloped (dead and diapause) as pupae and dead as adults inside the hosts were calculated by dividing the numbers of dead larvae, undeveloped pupae and dead adults by the total number of parasitized host eggs, respectively.

\section{Data analyses}

A two-way analysis of variance (ANOVA) was used to compare the performances of the six egg parasitoids, considering the effects of both parasitoid species (six levels) and host age (four levels), as well as their interaction on the number of parasitized hosts, developmental time, percent offspring emergence, percent female progeny and percentage of offspring dead as larvae, undeveloped as pupae or dead as adults inside the hosts. Prior to the ANOVAs, the percentage data were arcsine square-root-transformed to normalize variances and checked for the normality of residuals and homoscedasticity with Shapiro-Wilk tests. When the ANOVAs revealed significant effects of the factors, means were separated by Tukey's Honestly Significant Difference (HSD) test with an alpha equal to 0.05. All data analyses were performed using the SAS statistical software package (SAS Institute 2010, Cary, NC, USA).

\section{Results}

\section{Number of parasitized eggs}

All six parasitoids successfully parasitized JGS eggs of four tested ages, but the number of parasitized eggs was affected by parasitoid species, host age and their interaction (Table 2). The numbers of parasitized eggs (averaged from 2.60 to $23.53 \mathrm{eggs}$ ) was generally followed (in decreasing order) by A. japonicus, M. albitarsis, $M$. trabalae, A. fulloi, A. meilingensis and A. gansuensis at each host age (0-d old: $F_{5,84}=34.63, P<0.001 ; 10-d$ old: $F_{5,84}=22.32, P<0.001 ; 20-$ d old $F_{5,84}=61.62$, $P<0.001 ; 30$-d old: $F_{5,84}=48.87, P<0.001$ ) (Fig. 1a). All four Anastatus species parasitized more old (30 d, or 20 and $30 \mathrm{~d})$ than younger $(0,10$ and $20 \mathrm{~d}$, or 0 and $10 \mathrm{~d})$ eggs (A. fulloi: $F_{3,56}=15.62, P<0.001 ;$ A. gansuensis: 
Table 2 Results of two-way ANOVAs testing the effects of parasitoid species (PS), host age (HA) of $C$. japonica egg as well as their interaction on the performances of six eupelmid egg parasitoids in terms of the number of parasitized eggs, offspring emergence, developmental time and percent female progeny and the percentage of offspring dead as larvae, undeveloped as pupae or unemerged (dead) as adults inside the hosts

\begin{tabular}{lllrrl}
\hline Performance parameters & Source & Df & \multicolumn{1}{l}{ MS } & \multicolumn{1}{l}{ F } & \multicolumn{1}{l}{$P$} \\
\hline Number of host eggs & PS & 5 & 1696.34 & 129.14 & $<0.001$ \\
parasitized & HA & 3 & 353.68 & 26.92 & $<0.001$ \\
& PS $\times$ HA & 15 & 156.86 & 11.94 & $<0.001$ \\
Offspring emergence (\%) & PS & 5 & 169.35 & 1.21 & 0.303 \\
& HA & 3 & 102.18 & 0.73 & 0.534 \\
& PS $\times$ HA & 15 & 273.51 & 1.96 & 0.018 \\
Developmental time (d) & PS & 5 & 323.43 & 287.60 & $<0.001$ \\
& HA & 3 & 25.31 & 22.51 & $<0.001$ \\
& PS $\times$ HA & 15 & 2.57 & 2.28 & 0.004 \\
Female progeny (\%) & PS & 5 & 5121.99 & 31.52 & $<0.001$ \\
& HA & 3 & 293.36 & 1.81 & 0.146 \\
& PS $\times$ HA & 15 & 226.96 & 1.40 & 0.146 \\
Dead as larvae (\%) & PS & 5 & 66.67 & 1.02 & 0.408 \\
& HA & 3 & 18.12 & 0.28 & 0.842 \\
& PS $\times$ HA & 15 & 127.85 & 1.95 & 0.018 \\
Undeveloped as pupae & PS & 5 & 324.29 & 7.70 & $<0.001$ \\
$(\%)$ & HA & 3 & 60.98 & 1.45 & 0.229 \\
& PS $\times$ HA & 15 & 186.56 & 4.43 & $<0.001$ \\
Dead as unemerged adults & PS & 5 & 10.62 & 0.51 & 0.770 \\
$(\%)$ & HA & 3 & 12.34 & 0.59 & 0.622 \\
& PS $\times$ HA & 15 & 20.57 & 0.98 & 0.471 \\
\hline
\end{tabular}

$F_{3,56}=13.31, P<0.001 ;$ A. japonicus: $F_{3,56}=24.10$, $P<0.001 ;$ A. meilingensis: $\left.F_{3,56}=33.48, P<0.001\right)$ (Fig. 1a). However, M. albitarsis parasitized similar numbers of eggs at various ages, except that it parasitized more 20 -d old than 10-d old eggs $\left(F_{3,56}=4.09, P=0.011\right)$, and $M$. trabalae parasitized more young $(0,10$ and 20 -d old) than old (30 d) eggs $\left(F_{3,56}=6.28, P=0.001\right)$ (Fig. 1a).

\section{Developmental time}

Developmental time from oviposition to adult emergence was also affected by parasitoid species, host age and their interaction (Table 2). It was similar among different host ages for A. fulloi $\left(F_{3,56}=0.94, P=0.430\right)$ and A. gansuensis $\left(F_{3,56}=2.69, P=0.055\right)$, but generally increased with increasing host ages for $A$. japonicus $\left(F_{3,56}=5.32\right.$, $P=0.003)$, A. meilingensis $\left(F_{3,56}=13.50, P<0.001\right)$, M. albitarsis $\left(F_{3,56}=12.32, P<0.001\right)$ and $M$. trabalae $\left(F_{3,56}=13.75, P<0.001\right)$ (Table 3). Among parasitoid species, the developmental time was different at each host age (0-d old: $F_{5,84}=192.55, P<0.001 ; 10$-d old: $F_{5,84}=49.18$,
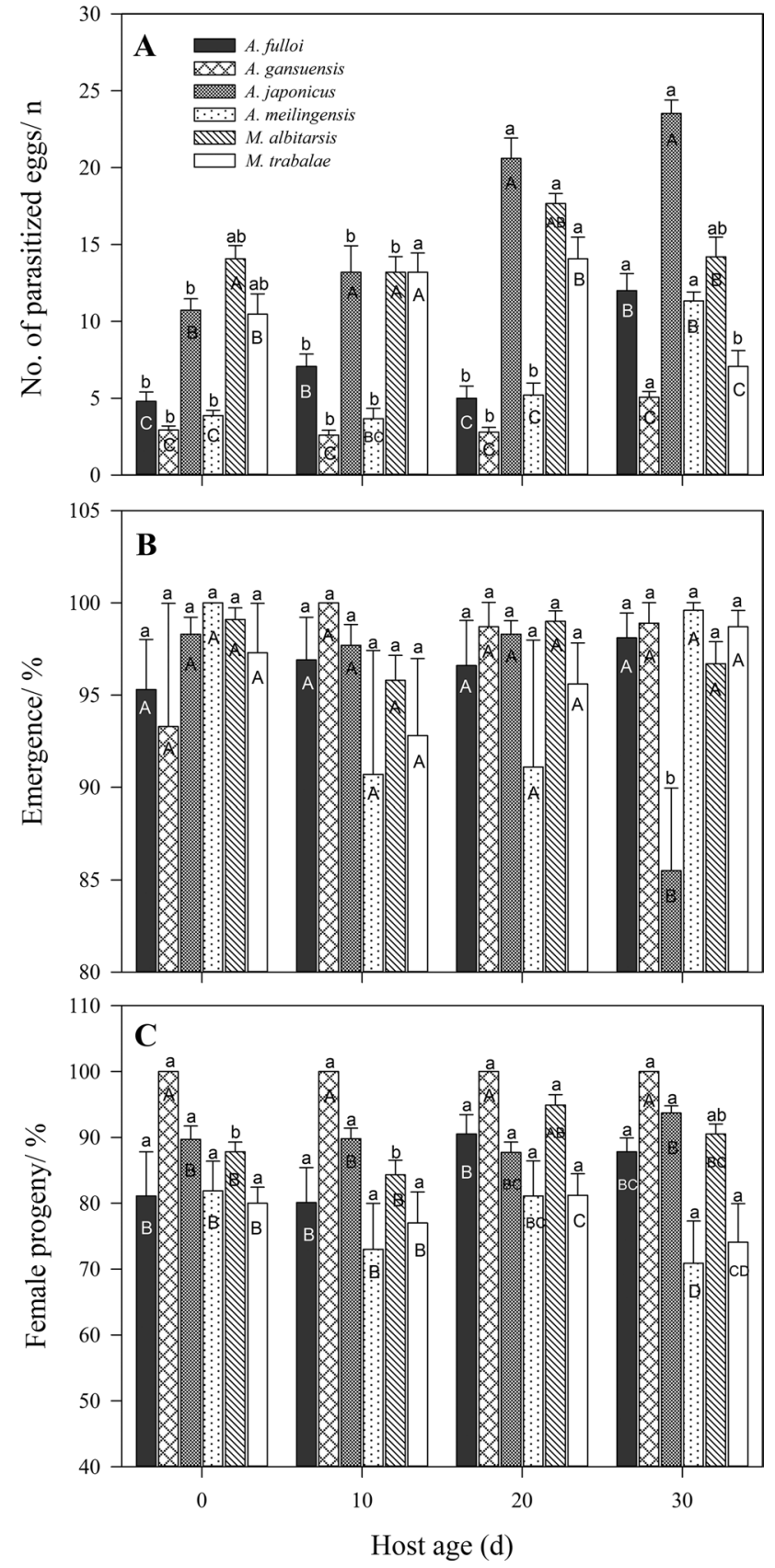

Fig. 1 Effects of host age of $C$. japonica eggs on the number of parasitized eggs (a), percent emergence (b) and percent female progeny (c) of each of the six eupelmid egg parasitoids. Bars refer to means \pm SE. The different lower-case letters above the same patterned bars indicate significant differences among different host ages for each parasitoid species, while the different upper-case letters above the bars indicate significant differences among different parasitoid species at each host age $(P<0.05$, Tukey's test $)$

$P<0.001 ; 20$-d old: $F_{5,84}=77.35, P<0.001 ; 30$-d old: $\left.F_{5,84}=59.87, P<0.001\right)$. Overall, A. gansuensis developed slowly while $M$. albitarsis developed fast when compared to other four parasitoid species (Table 3). 
Table 3 Developmental time and percentage of offspring dead as larvae, undeveloped as pupae or dead as adults by each of six eupelmid egg parasitoid species on different-aged $C$. japonica eggs

\begin{tabular}{|c|c|c|c|c|c|}
\hline \multirow[t]{2}{*}{ Performance parameters } & \multirow[t]{2}{*}{ Parasitoid species } & \multicolumn{4}{|l|}{ Host egg age $(d)^{\mathrm{a}}$} \\
\hline & & 0 & 10 & 20 & 30 \\
\hline \multirow[t]{6}{*}{ Developmental time $(d)$} & A. fulloi & $24.34 \pm 0.28$ a B & $24.61 \pm 0.30$ a B & $24.76 \pm 0.36$ a B & $25.08 \pm 0.33$ a B \\
\hline & A. gansuensis & $26.01 \pm 0.22 \mathrm{ab} A$ & $26.19 \pm 0.14 \mathrm{ab} \mathrm{A}$ & $25.84 \pm 0.16 \mathrm{~b} \mathrm{~A}$ & $26.50 \pm 0.15$ a A \\
\hline & A. japonicus & $22.54 \pm 0.12$ b C & $24.05 \pm 0.70 \mathrm{ab} \mathrm{BC}$ & $23.45 \pm 0.38 \mathrm{ab} \mathrm{C}$ & $25.22 \pm 0.55$ a B \\
\hline & A. meilingensis & $20.58 \pm 0.17$ c D & $20.94 \pm 0.21$ bc D & $21.63 \pm 0.24 \mathrm{~b} \mathrm{D}$ & $22.52 \pm 0.29$ a C \\
\hline & M. albitarsis & $19.25 \pm 0.10 \mathrm{~b} \mathrm{E}$ & $20.00 \pm 0.09$ a D & $19.54 \pm 0.10 \mathrm{~b} \mathrm{E}$ & $19.93 \pm 0.12$ a D \\
\hline & M. trabalae & $22.06 \pm 0.10 \mathrm{c} \mathrm{C}$ & $22.89 \pm 0.11 \mathrm{ab} \mathrm{C}$ & $22.66 \pm 0.17 \mathrm{~b} \mathrm{CD}$ & $23.28 \pm 0.16$ a C \\
\hline \multirow[t]{6}{*}{ Dead as larvae (\%) } & A. fulloi & $0.00 \pm 0.00 \mathrm{a} \mathrm{A}$ & $0.00 \pm 0.00 \mathrm{a} \mathrm{A}$ & $2.83 \pm 2.26 \mathrm{a} \mathrm{A}$ & $0.00 \pm 0.00 \mathrm{a} \mathrm{B}$ \\
\hline & A. gansuensis & $6.67 \pm 6.67$ a A & $0.00 \pm 0.00 \mathrm{a} \mathrm{A}$ & $1.33 \pm 1.33 \mathrm{a} \mathrm{A}$ & $0.00 \pm 0.00 \mathrm{a} \mathrm{B}$ \\
\hline & A. japonicus & $0.00 \pm 0.00 \mathrm{a} \mathrm{A}$ & $0.00 \pm 0.00 \mathrm{a} \mathrm{A}$ & $0.00 \pm 0.00 \mathrm{a} \mathrm{A}$ & $0.86 \pm 0.47 \mathrm{a} \mathrm{B}$ \\
\hline & A. meilingensis & $0.00 \pm 0.00 \mathrm{a} \mathrm{A}$ & $9.33 \pm 6.72$ a A & $3.33 \pm 3.33$ a A & $0.42 \pm 0.42$ a B \\
\hline & M. albitarsis & $0.00 \pm 0.00 \mathrm{~b} \mathrm{~A}$ & $0.00 \pm 0.00 \mathrm{~b} \mathrm{~A}$ & $0.00 \pm 0.00 \mathrm{~b} \mathrm{~A}$ & $3.30 \pm 1.19 \mathrm{a} \mathrm{A}$ \\
\hline & M. trabalae & $0.00 \pm 0.00 \mathrm{a} \mathrm{A}$ & $1.85 \pm 1.39 \mathrm{a} \mathrm{A}$ & $0.00 \pm 0.00 \mathrm{a} \mathrm{A}$ & $0.00 \pm 0.00 \mathrm{a} \mathrm{B}$ \\
\hline \multirow[t]{6}{*}{ Undeveloped as pupae $(\%)^{\mathrm{b}}$} & A. fulloi & $4.72 \pm 2.72 \mathrm{a} \mathrm{A}$ & $0.83 \pm 0.83$ a $\mathrm{A}$ & $0.61 \pm 0.61 \mathrm{a} \mathrm{AB}$ & $0.83 \pm 0.83 \mathrm{a} \mathrm{B}$ \\
\hline & A. gansuensis & $0.00 \pm 0.00$ a B & $0.00 \pm 0.00$ a A & $0.00 \pm 0.00$ a B & $0.00 \pm 0.00 \mathrm{a} \mathrm{B}$ \\
\hline & A. japonicus & $1.22 \pm 0.84 \mathrm{~b} \mathrm{~B}$ & $1.61 \pm 0.98 \mathrm{~b} \mathrm{~A}$ & $1.46 \pm 0.72 \mathrm{~b} \mathrm{AB}$ & $13.15 \pm 4.57 \mathrm{a} \mathrm{A}$ \\
\hline & A. meilingensis & $0.00 \pm 0.00 \mathrm{a} \mathrm{B}$ & $0.00 \pm 0.00 \mathrm{a} \mathrm{A}$ & $0.00 \pm 0.00 \mathrm{a} \mathrm{B}$ & $0.00 \pm 0.00 \mathrm{a} \mathrm{B}$ \\
\hline & M. albitarsis & $0.00 \pm 0.00 \mathrm{~b} \mathrm{~B}$ & $3.83 \pm 1.28 \mathrm{a} \mathrm{A}$ & $1.04 \pm 0.56 \mathrm{~b} \mathrm{AB}$ & $0.00 \pm 0.00 \mathrm{~b} \mathrm{~B}$ \\
\hline & M. trabalae & $0.00 \pm 0.00 \mathrm{a} \mathrm{B}$ & $3.48 \pm 2.67 \mathrm{a} \mathrm{A}$ & $4.40 \pm 2.23 \mathrm{a} \mathrm{A}$ & $1.30 \pm 0.89$ a B \\
\hline \multirow[t]{6}{*}{ Dead as unemerged adults (\%) } & A. fulloi & $0.00 \pm 0.00 \mathrm{a} \mathrm{A}$ & $2.22 \pm 2.22 \mathrm{a} \mathrm{A}$ & $0.00 \pm 0.00 \mathrm{a} \mathrm{A}$ & $1.11 \pm 1.11 \mathrm{a} \mathrm{A}$ \\
\hline & A. gansuensis & $0.00 \pm 0.00 \mathrm{a} \mathrm{A}$ & $0.00 \pm 0.00 \mathrm{a} \mathrm{A}$ & $0.00 \pm 0.00 \mathrm{a} \mathrm{A}$ & $1.11 \pm 1.11 \mathrm{a} \mathrm{A}$ \\
\hline & A. japonicus & $0.48 \pm 0.48$ a A & $0.68 \pm 0.47$ a A & $0.28 \pm 0.28$ a A & $0.48 \pm 0.33$ a A \\
\hline & A. meilingensis & $0.00 \pm 0.00 \mathrm{a} \mathrm{A}$ & $0.00 \pm 0.00 \mathrm{a} \mathrm{A}$ & $2.22 \pm 2.22 \mathrm{a} \mathrm{A}$ & $0.00 \pm 0.00 \mathrm{a} \mathrm{A}$ \\
\hline & M. albitarsis & $0.90 \pm 0.62$ a A & $0.35 \pm 0.35$ a A & $0.00 \pm 0.00 \mathrm{a} \mathrm{A}$ & $0.00 \pm 0.00 \mathrm{a} \mathrm{A}$ \\
\hline & M. trabalae & $2.67 \pm 2.67 \mathrm{a} \mathrm{A}$ & $1.84 \pm 1.12 \mathrm{a} \mathrm{A}$ & $0.00 \pm 0.00 \mathrm{a} \mathrm{A}$ & $0.00 \pm 0.00 \mathrm{a} \mathrm{A}$ \\
\hline
\end{tabular}

${ }^{a}$ Values $($ mean \pm SE) followed by the different upper-case letters within a column and the different lower-case letters within a row indicate significant different among parasitoid species and host ages, respectively $(P<0.05$, Tukey's HSD test)

${ }^{\mathrm{b}}$ All undeveloped A. japonicus pupae were alive (in diapause) while all undeveloped pupae of other parasitoid species were dead at the time of dissections

\section{Offspring survival and emergence}

During the dissections, dead larvae, pupae or adults were found inside the hosts in all parasitoid species, except that all undeveloped $A$. japonicus were alive (in diapause) and no A. gansuensis and A. meilingensis pupae were dead (Table 3). Overall, percentages of offspring dead as larvae $(0.0-9.3 \%)$, dead as pupae $(0.0-4.7 \%)$, diapausing as pupae $(1.2-13.1 \%)$ or dead as adults $(0.0-2.7 \%)$ were low in all treatments (Table 3 ).

The percentage of offspring dead at the larval stage was not affected by parasitoid species and host age but was affected by the interaction of these two factors (Table 2). It was similar for A. fulloi $\left(F_{3,56}=1.56, P=0.208\right)$, A. gansuensis $\left(F_{3,56}=0.87, P=0.460\right)$, A. meilingensis $\left(F_{3,56}=1.31\right.$, $P=0.280)$ and $M$. trabalae $\left(F_{3,56}=1.75, P=0.167\right)$, but different for A. japonicus $\left(F_{3,56}=3.42, P=0.023\right)$ and $M$. albitarsis $\left(F_{3,56}=7.72, P<0.001\right)$ among different host ages
(Table 3). It was also similar in $0 \mathrm{~d}\left(F_{5,84}=1.00, P=0.423\right)$, $10 \mathrm{~d}\left(F_{5,84}=1.77, P=0.127\right)$ and $20 \mathrm{~d}\left(F_{5,84}=0.77\right.$, $P=0.575)$ old eggs among different parasitoid species (Table 3). However, a higher percentage of $M$. albitarsis offspring dead as larvae in 30-d old than other aged eggs $\left(F_{5,84}=5.54, P<0.001\right)$ (Table 3).

The percentage of undeveloped pupae was affected by parasitoid species but was not affected by host age or the interaction of these two factors (Table 2). It was similar for A. fulloi $\left(F_{3,56}=1.72, P=0.174\right)$ or $M$. trabalae $\left(F_{3,56}=1.25\right.$, $P=0.300$ ) among different host eggs (Table 3 ). However, a higher percentage of $A$. japonicus pupae failed to develop in 30 -d old than other aged eggs $\left(F_{3,56}=5.95, P<0.001\right)$, and a lower percentage of $M$. albitarsis pupae failed to develop in 10 -d old than other aged eggs $\left(F_{3,56}=6.72, P<0.001\right)$. The percentage of undeveloped pupae was different in 0-d old $\left(F_{5,84}=2.65, P=0.029\right), 20$ d-old $\left(F_{5,84}=2.63, P=0.029\right)$ and 30-d old $\left(F_{5,84}=7.31, P<0.001\right)$ eggs, but was similar 
in 10 -d old $\left(F_{5,84}=1.64, P=0.159\right)$ eggs among different parasitoid species (Table 3 ). There was no significant effect of host age, parasitoid species or their interaction on the percentage of unemerged adult wasps (Tables 2-3).

Consequently, offspring emergence was high $(>90 \%)$ in all treatments (Fig. 1b). Neither parasitoid species nor host age affected offspring emergence (Table 2). There was, however, an interactive effect between the parasitoid species and host age on the offspring emergence. It was no different for A. fulloi $\left(F_{3,56}=0.19, P=0.905\right)$, A. gansuensis $\left(F_{3,56}=0.75\right.$, $P=0.527), A$. meilingensis $\left(F_{3,56}=1.23, P=0.309\right)$, M. albitarsis $\left(F_{3,56}=2.41, P=0.077\right)$ or $M$. trabalae $\left(F_{3,56}=0.91\right.$, $P=0.442$ ) among different host ages (Fig. 1b). However, offspring emergence of $A$. japonicus was lower from the oldest (30-d old) than young $(0,10$, or 20 -d old $)$ eggs $\left(F_{3,56}=7.03\right.$, $P=0.0004$ ) (Fig. 1b), and this was largely due to the diapause of undeveloped pupae.

\section{Offspring sex ratio}

Regardless of the host age, all six parasitoids were strongly female biased ( $>70 \%$ females), except for A. gansuensis which produced $100 \%$ female offspring (Fig. 1c). Percentage of female progeny was affected by parasitoid species only (Table 2). It was no different for A. fulloi $\left(F_{3,56}=1.07\right.$, $P=0.368)$, A. gansuensis $\left(F_{3,56}=0.88, P=0.527\right)$, A. japonicus $\left(F_{3,56}=2.14, P=0.105\right)$, A. meilingensis $\left(F_{3,56}=1.38\right.$, $P=0.260)$, or $M$. trabalae $\left(F_{3,56}=0.13, P=0.942\right)$ among different host ages. However, $M$. albitarsis produced more female biased progeny from 20-d old than 0 or 10-d-old eggs $\left(F_{3,56}=7.74, P<0.001\right)$. Overall, A. gansuensis, A. japonicus, and $M$. albitarsis produced more female biased progeny than the other three parasitoid species at all host ages (0-d old: $F_{5,84}=6.99, P<0.001 ; 10$-d old: $F_{5,84}=6.57, P<0.001$; 20-d old: $F_{5,84}=10.35, P<0.001 ; 30$-d old: $F_{5,84}=14.12$, $P<0.001)$.

\section{Discussion}

We compared the relative performances of six indigenous eupelmid egg parasitoids on different-aged JGS eggs, with an effort to identify the best candidate agents for the control of this emerging pest as well as suitable host ages for improving rearing and field release protocols of selected parasitoids. We demonstrated successful parasitism of JGS eggs by all six parasitoids and the suitability of various-aged JGS eggs for these parasitoids.

Eggs (except for diapausing eggs) develop in a short period of time and the quality of a host egg as a resource for an egg parasitoid decreases rapidly as the egg ages. Also, host eggs could become less acceptable due to increased hardness of the eggshell or less detectable due to fading host recognition cues over time (Vinson 1998). Therefore, many egg parasitoids preferentially oviposit in young eggs, and young eggs can be more suitable than old eggs for the development of parasitoid offspring (Vinson 1998; Zhang et al. 2014; Hou et al. 2018). For example, Trichogramma ostriniae Pang \& Chen, T. japonicum Ashmend, T. dendrolimi Matsumura, and T. chilonis Ishii (all Hymenoptera: Trichogrammatidae) all showed an oviposition preference for young eggs of Chilo suppressalis (Walker) (Lepidoptera: Crambidae) and Mythimna separata (Walker) (Lepidoptera: Noctuidae) (Zhang et al. 2014; Hou et al. 2018). However, in this study, we found (1) the effect JGS egg age on the preference of the six tested egg parasitoids (in terms of the number of parasitized hosts) varied with the species of parasitoid; the four Anastatus species preferred old than young eggs while the two Mesocomys appeared not to show a strong host age preference or preferred less for the oldest eggs; and (2) various-aged eggs seem to be suitable for all six parasitoids, as offspring survival was high $(>90 \%)$ and all parasitoids were female-biased at all host ages, although there exist slight variations in these fitness paraments across parasitoid species or host ages.

There may be several reasons why these six parasitoids did not show a strong preference for young JGS eggs and why various-aged eggs were suitable for these parasitoids. First, the JGS eggs used in this study were in diapause. Despite these eggs were differently aged, they likely offered nutrition of similar quality for the development of the parasitoids. Second, JGS egg has a hard surface (Fig. 2), and there must exist variations among the six parasitoid species in their abilities to penetrate the shell of JGS egg. Old JGS eggs could be hard to be penetrated by the Mesocomys, or they may take longer to parasitize the old than young eggs (host handling time); both situations would result in reduced parasitization efficiency on old host eggs. However, this may be not the case for the Anastatus. Instead, it could be an advantage for the Anastatus to accept old rather than young eggs if there is no difference in host handling time among different host eggs and no obvious fitness costs for offspring development in old hosts (as showed here). Because these eggs parasitoids likely overwinter synchronously with their host eggs for several months in the field, old eggs could be more resistant to unpredictable environmental conditions. Similar results were observed in the egg parasitoid Telenomus euproctidis Wilcox (Hymenoptera: Scelionidae), whose offspring had high survival in overwintering eggs of Euproctis pseudoconspersa Strand (Lepidoptera: Erebidae) (Ai et al. 2000). In general, all six egg parasitoids were still rather flexible in accepting JGS eggs, and this flexibility would allow them to explore a wide range of aged and diapausing JGS eggs. We must point out that it is possible that some individual parasitoids might had died at the egg stage, but they could be unrecognizable in the dead hosts during 


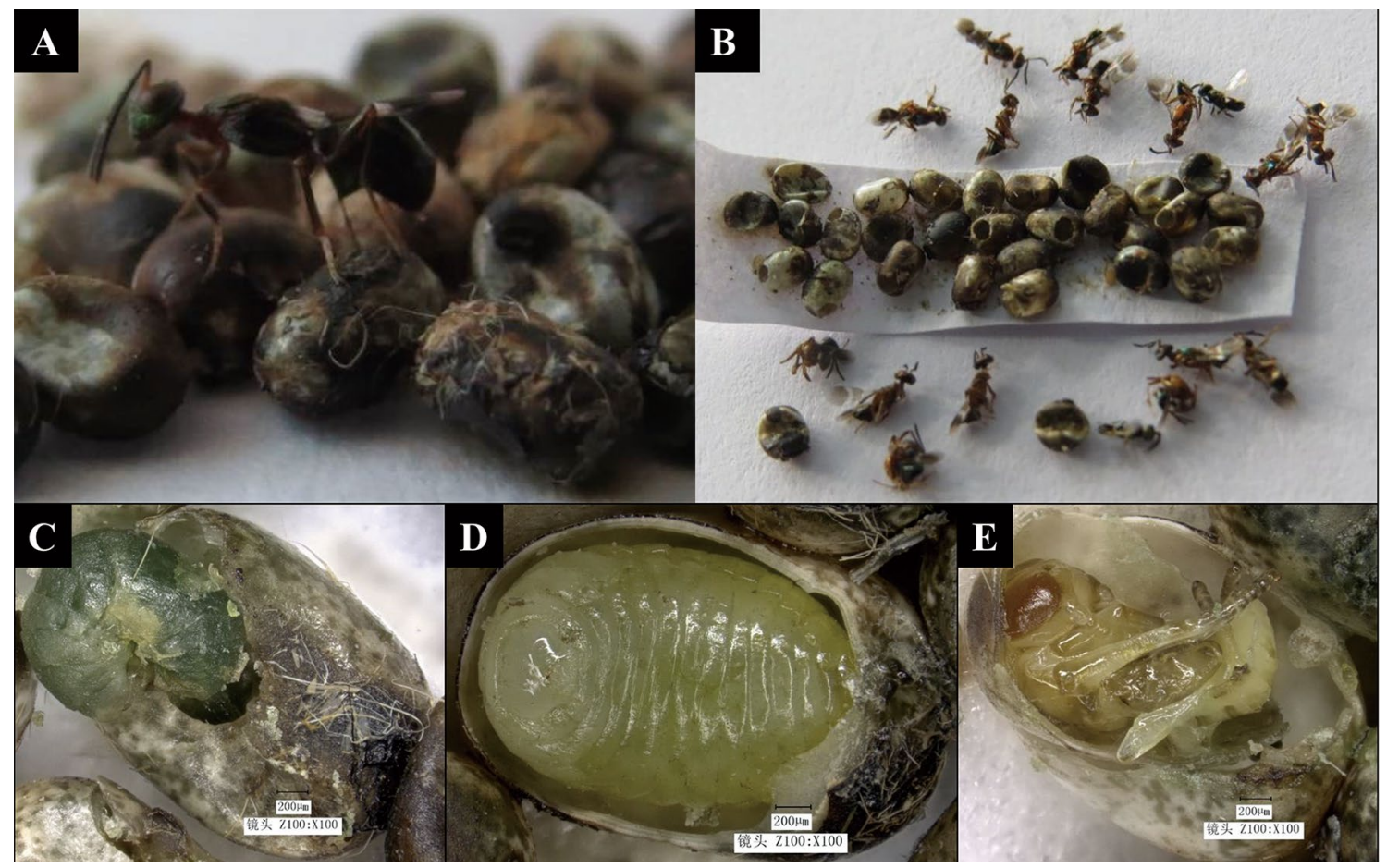

Fig. 2 Images of an adult female parasitizing C. japonica egg (a), emerged adults (b), dead larva (c), and alive (in diapause) pre-pupa (d) and pupa (e) of A. japonicus

the dissections. Thus, offspring survival could be slightly overestimated. Given the overall low percentages of dead host eggs across all parasitoid species and host age treatments $(<10 \%)$, any differences resulting from the overestimation could be negligible.

Relatively, A. gansuensis developed slowly while $M$. albitarsis developed faster when compared to the other four parasitoid species that had similar developmental times. The developmental time was independent of host age in A. fulloi and $A$. gansuensis but slightly increased with host age in the other four parasitoids. To maximize their chances of successful parasitism, egg parasitoids often delay host development or speed up progeny development when ovipositing in an older host (Vinson 1998). For example, development of A. bifasciatus was delayed when attacking old eggs of Thaumetopoea solitaria (Freyer) (Lepidoptera: Notodontidae) or H. halys eggs (Boyadzhiev et al. 2017; Stahl et al. 2018b). As discussed above, diapausing JGS eggs may do not undergo significant changes of host quality over time, and for this reason, these parasitoids may be unnecessary to adjust their developmental times. Dead adults of all the six parasitoids were found inside JGS eggs, and this happened apparently because some adult wasps were unable to successfully gnaw a hole out of the eggs. This also occurred in other parasitoids such as T. ostriniae, T. embryophagum Hartig, and T. piceum Dyurich, where adult wasps failed to form an emergence hole for emergence (e.g., Hassan et al.
2004; Li et al. 2019). We suspect that adult wasps of these four species may take longer to emerge from old than young host eggs.

Interestingly, A. gansuensis produced all female offspring on JGS eggs. It could occasionally produce a few male offspring as we recently noticed that this parasitoid had a 113:1 ratio of female to male offspring when reared from A. pernyi eggs (Chen et al. unpubl. data). The parthenogenetic reproduction of A. gansuensis is an advantage if the parasitoid must be mass reared, because it would be cheaper to produce than sexual forms. Most hymenopteran species are haplodiploid, i.e., male (haploid) developed from unfertilized eggs while female (diploid) developed from fertilized eggs (Heimpel and de Boer 2008). Female-producing parthenogenesis (thelytoky) can be genetic or due to infections by endosymbiotic bacteria of the genera Cardinium, Wolbachia, and Rickettsia (Simon et al. 2003; Rabeling and Kronauer 2013; Monti et al. 2016). For example, parthenogenetic reproductions in Encarsia formosa Gahan (Hymenoptera: Aphelinidae) (Zchori-Fein et al. 2001), Plagiomerus diaspidis Crawford (Hymenoptera: Encyrtidae) (Zchori-Fein and Perlman 2004) and Leptocybe invasa Fisher \& La Salle (Hymenoptera: Eulophidae) (Nugnes et al. 2015) were associated with the infection of Wolbachia, Cardinium, and Rickettsia, respectively. Whether or not the A. gansuensis population was infested by endosymbionts is unknown and this deserves further study. 
It is likely that these six egg parasitoids diapause in host eggs when they attack the hosts in later fall. Diapause does occur under a combination of low temperature and short photoperiod in several closely related species such as M. pulchriceps Cameron (Vanden Berg 1971), A. umae Bouček (=A. madagascariensis Risbec) (Narasimham and Sankaran 1982), and A. bifasciatus (Stahl et al. 2018b). Among the six parasitoid species, A. japonicus was previously reported to enter diapause as pre-pupae in A. pernyi eggs in China (Zhao et al. 2019) or as mature larvae inside the gypsy moth eggs in Ontario, Canada (Sullivan et al. 1977). The different diapausing stages as reported in the two studies could be due to different adaptions by two different geographical populations to the local environments. However, the tested laboratory conditions in the current study would not favor diapause, still, a small portion of A. japonicus went diapause as pre-pupae. This partial diapause of A. japonicus seems to be induced by the diapausing hosts. This also occurred in other parasitoids. For example, Encarsia scapeata Rivnay entered diapause when it was reared on diapausing host Bemisia tabaci Gennadius (Hemiptera: Aleyrodidae) (Gerling et al. 2009). Partial diapause could be an adaptive "risk-spreading" strategy for the parasitoid to copy with unpredictable environments (Hopper 1999).

In conclusion, all the six egg parasitoids have the potential for conservative and augmentative biological control of JGS. Fast development in M. albitarsis, parthenogenetic reproduction in A. gansuensis and partial diapause in $A$. japonicus all could be important attributes as biological control agents. Overall, A. japonicus, M. albitarsis and $M$. trabalae are recommended as the best candidate agents. These parasitoids could be mass-reared and released during the fall for the suppression of diapausing JGS eggs. It is also worth of mentioning that these parasitoids can be reared on the factitious host $A$. pernyi as we showed here that the tested parasitoids reared from A. pernyi eggs effectively parasitized JGS eggs. Antheraea pernyi eggs $(104.96 \pm 0.57 \mathrm{eggs} / \mathrm{g})$ were about twice larger than JGS eggs (297.62 \pm 0.49 eggs /g), and consequently, female parasitoids (e.g., M. trabalae) developed from the $A$. pernyi eggs $(4.657 \pm 0.017 \mathrm{um})$ were about twice larger than those reared from the JGS eggs $(2.058 \pm 0.015 \mathrm{um})$ (Chen et al. unpubl. data). In general, the body size of adult parasitoids is often positively correlated with many other fitness components (e.g., Quicke 1997; Morris and Fellowes 2002; Wang and Messing 2004). However, further detailed studies are needed for a better understanding of the effect of natal host on the parasitoids' demographic parameters (e.g., intrinsic rate of increase) and other fitness attributes. Further studies are also needed to demonstrate the efficiency of these parasitoids against JGS via augmentative release in the field.

\section{Author contributions}

LSZ, YMC and ND scoped and designed research. YMC, XRQ and ZYR conducted experiments and collected the data. YMC and XW performed data analyses. YMC and AI wrote the early draft. LSZ, XW and THL edited it. All authors read and approved the manuscript.

Acknowledgments We are grateful to Dr. Gary Gibson (Honorary Research Associate, Agriculture and Agri-Food Canada, Canadian National Collection of insects) for the identification of six Eupelmidae species. This research was funded by the National Key R\&D Program of China (Nos: 2017YFE0104900 and 2017YFD0201000), and Gansu Provincial Fiscal Science and Technology Award and Compensation Project (2018-01).

\section{Compliance with ethical standards}

Conflict of interest The authors declare no conflicts of interest.

\section{References}

Abarenkov K (2019) Life Sciences EUO, Estonian University of Life Sciences. PlutoF. Occurrence dataset. https://doi.org/10.15156/ bio/587441 accessed via GBIF.org on 2019-12-28. https://www. gbif.org/occurrence/1148336835. Accessed 28 Dec 2019

Abram PK, Talamas EJ, Acheampong S, Mason PG, Gariepy TD (2019) First detection of the samurai wasp, Trissolcus japonicus (Ashmead) (Hymenoptera, Scelionidae), in Canada. J Hym Res 68:29-36

Ai H, Zhao S, She Z (2000) A study on natural enemies of Euproctis pseudoconspersa Strand. Entomol J East China 9:67-72

Boyadzhiev P, Mirchev P, Georgiev G (2017) Species of the Genus Ooencyrtus Ashmead, 1900 (Hymenoptera: Encyrtidae), egg parasitoids of Thaumetopoea solitaria (Lepidoptera: Notodontidae) in Bulgaria. Acta Zool Bulg 1:107-112

Chen YM, Gibson GAP, Peng LF, Iqbal A, Zang LS (2019) Anastatus Motschulsky (Hymenoptera, Eupelmidae): egg parasitoids of Caligula japonica Moore (Lepidoptera, Saturniidae) in China. ZooKeys 881:109-134

Chen YM, Sun JW, Iqbal A, Lu R, Wang H, Zang LS (2020) An investigation of Caligula japonica (Lepidoptera: Saturniidae) egg distribution and associated parasitoids on walnut trees (Juglans regia L.) in northwestern China. Int J Pest Manag. In press

Clausen CP (1927) The bionomics of Anastatus albitarsis Ashm., parasitic in the eggs of Dictyoploca japonica Moore (Hymen.). Ann Entomol Soc Am 20:461-473

Desneux N, Decourtye A, Delpuech JM (2007) The sublethal effects of pesticides on beneficial arthropods. Annu Rev Entomol 52:81-106

Dong DJ (2013) Toxicity determination and control effect of several pesticides against Dictyoploca japonica Butler. Forest Pest Dis 32:38-40

Fang HL, Lian YY, Zhu JR, Zhang AX (1995) Study on the dynamics of Anastatus albitarsis in the forest. J Zhejiang For Coll 12:73-78

Fischbein D, Corley JC (2015) Classical biological control of an invasive forest pest: a world perspective of the management of Sirex noctilio using the parasitoid Ibalia leucospoides (Hymenoptera: Ibaliidae). Bull Entomol Res 105:1-12

Fischbein D, Lantschner MV, Corley JC (2019) Modelling the distribution of forest pest natural enemies across invaded areas: 
towards understanding the influence of climate on parasitoid establishment success. Biol Control 132:177-188

Gerling D, Erel E, Guershon M, Inbar M (2009) Bionomics of Encarsia scapeata Rivnay (Hymenoptera: Aphelinidae), tritrophic relationships and host-induced diapause. Biol Control 49:201-206

Gibson GAP (1995) Parasitic wasps of the subfamily Eupelminae: classification and revision of world genera (Hymenoptera: Chalcidoidea: Eupelmidae). Mem Entomol Int 5:1-421

Gibson GAP (1997) Chapter 2. Morphology and Terminology. In: Gibson GAP, Huber JT, Woolley JB (eds) Annotated keys to the genera of nearctic chalcidoidea (hymenoptera). NRC Research Press, Ottawa, pp 16-44

Gibson GAP (2011) The species of Eupelmus (Eupelmus) Dalman and Eupelmus (Episolindelia) Girault (Hymenoptera: Eupelmidae) in North America north of Mexico. Zootaxa 2951:1-97

Gibson GAP, Fusu L (2016) Revision of the Palaearctic species of Eupelmus (Eupelmus) Dalman (Hymenoptera: Chalcidoidea: Eupelmidae). Zootaxa 4081:1-331

Hassan SA, Liscsinszky H, Zhang G (2004) The oak-silkworm egg Antheraea pernyi (Lepidoptera: Anthelidae) as a mass rearing host for parasitoids of the genus Trichogramma (Hymenoptera: Trichogrammatidae). Biocontrol Sci Techn 14:269-279

Hebert PDN, Cywinska A, Ball SL, de Waard JR (2003) Biological identifications through DNA barcodes. P Roy Soc B-Biol Sci 270:313-321

Heimpel GE, de Boer JG (2008) Sex determination in the hymenoptera. Annu Rev Entomol 53:209-230

Hirose Y (1964) The activity of the egg parasite of the pine-moth, Dendrolimus spectabilis Butler in the Japanese black pine forest on the sea coast. Sci Bull Fac Agr Kyushu Univ 21:13-24

Hopper KR (1999) Risk-spreading and bet-hedging in insect population biology. Annu Rev Entomol 44:535-560

Hou YY, Yang X, Zang LS, Zhang C, Monticelli LS, Desneux N (2018) Effect of oriental armyworm Mythimna separata egg age on the parasitism and host suitability for five Trichogramma species. J Pest Sci 91:1181-1189

Huang NX, Jaworski CC, Desneux N, Zhang F, Yang PY, Wang S (2020) Long-term, large-scale releases of Trichogramma promotes pesticide decrease in maize in Jilin province, Northern China. Entomol Gen. https://doi.org/10.1127/entomologi a/2020/0994

Iqbal A, Chen YM, Hou YY, Zhang L, Desneux N, Zang LS (2019) Factitious host species impact on the outcome of multiparasitism between egg parasitoids. J Pest Sci 92:1261-1269

Kawasaki H, Sato H (1985) The tanning agent in the silk of the Japanese giant silkmoth, Dictyoploca japonica Butler. Insect Biochem 15:681-684

Li DS, Liao CY, Zhang BX, Song ZW (2014) Biological control of insect pests in litchi orchards in China. Biol Control 68:23-36

Li TH, Tian CY, Zang LS, Hou YY, Ruan CC, Yang XB, Lucie M, Desneux N (2019) Multiparasitism with Trichogramma dendrolimi on egg of Chinese oak silkworm, Antheraea pernyi, enhances emergence of Trichogramma ostriniae. J Pest Sci 92:707-713

Liu SY, Luo YF (2008) Application of Beauveria bassiana (Balsamo) Vuillemin for the control of Dictyoploca japonica Moore. Guizhou For Sci Techn 1:36-39

Mills N (2010) Egg parasitoids in biological control and integrated pest management. In: Consoli FL, Parra JPR, Zucchi RA (eds) Egg parasitoids in agroecosystems with emphasis on Trichogramma. Springer, New York, pp 389-411

Monti MM, Francesco N, Liberata G, Marco G, Umberto B (2016) No evidence of parthenogenesis-inducing bacteria involved in Thripoctenus javae thelytoky: an unusual finding in Chalcidoidea. Entomol Exp App 160:292-301
Morris R, Fellowes M (2002) Learning and natal host influence host preference, handling time and sex allocation behaviour in a pupal parasitoid. Behav Ecol Sociobiol 51:386-393

Narasimham AU, Sankaran T (1982) Biology of Anastatus umae (Hymenoptera: Eupelmidae), an oothecal parasite of Neostylopyga rhombifolia. Colemania 1:135-140

Nashiki Y (2019) Insect specimens of Komatsu City Museum. Version 1.1. National Museum of Nature and Science, Japan. Occurrence dataset. https://doi.org/10.15468/8reiif accessed via https://www. gbif.org/ on 2019-12-28. Accessed 28 Dec 2019

Nugnes F, Gebiola M, Monti MM, Gualtieri L, Giorgini M, Wang J, Bernardo U, Munderloh UG (2015) Genetic diversity of the invasive gall wasp Leptocybe invasa (Hymenoptera: Eulophidae) and of its Rickettsia endosymbiont, and associated sex-ratio differences. PLoS ONE 10:e0124660

Nurindah, Bronwen WC, Gordh G (1999) Influence of rearing hosts on host size acceptance by Trichogramma australicum. Biocontrol 44:129-141

Ohno Y, Umeki K, Watanabe I, Takiya M, Terazawa K, Hara H, Matsuki S (2008) Variation in shoot mortality within crowns of severely defoliated Betula maximowicziana trees in Hokkaido, northern Japan. Ecol Res 23:355-362

Pizzol J, Desneux N, Wajnberg E, Thiéry D (2012) Parasitoid and host egg ages have independent impact on various biological traits in a Trichogramma species. J Pest Sci 85:489-496

Qiao X, Wang YC, Wu G, Wang SY, Hu JZ, Liu TX, Feng SQ (2014) Occurrence reasons and control measures of Caligula japonica in Longnan city of China. Plant Dis Pests 5:38-41

Qu YY, Xiao D, Li JY, Chen Z, Biondi A, Desneux N, Gao XW, Song D (2015) Sublethal and hormesis effects of imidacloprid on the soybean aphid Aphis glycines. Ecotoxicology 24:479-487

Quicke DJ (1997) Parasitic Wasps. Chapman and Hall, London

Rabeling C, Kronauer DJ (2013) Thelytokous parthenogenesis in eusocial hymenoptera. Annu Rev Entomol 58:273-292

SAS Institute (2010) SAS/STAT v.9.1. SAS Institute, Cary, NC, USA

Sheng JK, Wang GH, Yu YX, Yu JC (1997) Four new species of Anastatus Motschulsky (Hymenoptera: Euplemidae) from China. Entomotaxonomia 19:58-64

Sheng JK, Yu YX (1998) Two new species of Anastatus Motschulsky from China (Hymenoptera, Chalcidoidea, Eupelmidae). Wuyi Sci J 14:5-8

Simon JC, Delmotte F, Rispe C, Crease T (2003) Phylogenetic relationships between parthenogens and their sexual relatives: the possible routes to parthenogenesis in animals. Biol J Linn Soc 79:151-163

Smith SM (1996) Biological control with Trichogramma: advances, success, and potential of their use. Annu Rev Entomol 41:375-406

Stahl JM, Babendreier D, Haye T (2018a) Using the egg parasitoid Anastatus bifasciatus against the invasive brown marmorated stink bug in Europe: can non-target effects be ruled out? J Pest Sci 91:1005-1017

Stahl JM, Babendreier D, Haye T (2018b) Life history of Anastatus bifasciatus, a potential biological control agent of the brown marmorated stink bug in Europe. Biol Control 129:178-186

Sullivan C, Griffiths K, Wallace D (1977) Low winter temperatures and the potential for establishment of the egg parasite Anastatus disparis (Hymenoptera: Eupelmidae) in Ontario populations of the gypsy moth. Can Entomol 109:215-220

Talamas EJ, Herlihy MV, Dieckhoff C, Hoelmer KA, Buffington ML, Bon M-C, Weber DC (2015) Trissolcus japonicus (Ashmead) emerges in North America. J Hymenopt Res 43:119-128

Teng XW, Ni LX (1989) Bionomics of Pseudanastatus albitarsis Ashmead and its utiuzation for control of Dendrolimus punctatus Walker. Acta Entomol Sin 32:451-458

Tetsu A, Ikuo I, Fumihiko K, Chiharu S (1974) Electron microscope observations on the maturation process of the Nucleopolyhedrosis 
viruses of the oriental tussock moth, Euproctis subflava Bremer and the Japanese giant silkworm, Dictyoploca japonica Butler. Jap J App Entomol Z 18:189-197

Vanden Berg MA (1971) Studies on the induction and termination of diapause in Mesocomys pulchriceps Cam. (Hymenoptera: Eupelmidae) an egg parasite of Saturniidae (Lepidoptera). Phytophylactica $3: 85-88$

Vinson SB (1976) Host selection by insect parasitoids. Ann Rev Entomol 21:109-133

Vinson SB (1998) The general host selection behavior of parasitoid Hymenoptera and a comparison of initial strategies utilized by larvaphagous and oophagous species. Biol Control 11:79-96

Wang XG, Messing RH (2004) Fitness consequence of body sizedependent host species selection in a generalist ectoparasitoid. Behav Ecol Sociobiol 56:513-522

Wang YX, Qiao X, Wang ZK (2012) Pharmacodynamic study on different insecticide for Caligula japonica Moore. Modern Agr Sci Techn 14:95-96

Watt TJ, Duan JJ, Tallamy DW, Judith HG (2015) Effect of parasitoid: host ratio and group size on fitness of Spathius galinae (Hymenoptera: Braconidae): implications for mass-rearing. J Econ Entomol 108:951-956

Weisenburger DD (1993) Human health effects of agrichemical use. Hum Pathol 24:571-576

Yang BS, Li J, Li YR, Wang Z (2008a) Genetic diversity assessment of Dictyoploca japonica from different areas. Chin Bull Entomol 45:418-421

Yang BS, Zhang XK, Cao LJ, Qin L (2008b) Biological characteristics of Dictyoploca japonica Moore and the technology for prevention and control. Agrochemicals 47:153-154

Yang ZQ, Wei JR, Wang XY (2006) Mass rearing and augmentative releases of the native parasitoid Chouioia cunea for biological control of the introduced fall webworm Hyphantria cunea in China. Biocontrol 51:411-418
Yao YX, Yang ZQ, Zhao WX (2009) Descriptions of four new species in the genus Mesocomys (Hymenoptera, Eupelmidae) parasitizing eggs of defoliators from China. Acta Zootaxonomica Sin $34: 155-160$

Yuan XH, Song LW, Zhang JJ, Zang LS, Zhu L, Ruan CC, Sun GZ (2012) Performance of four Chinese Trichogramma species as biocontrol agents of the rice striped stem borer, Chilo suppressalis, under various temperature and humidity regimes. J Pest Sci 85:497-504

Zang LS, Wang S, Zhang F, Desneux N (2021) Biological control with Trichogramma in China: history, present status and perspectives. Annu Rev Entomol. https://doi.org/10.1146/annurev-ento-06012 0-091620

Zchori-Fein E, Gottlieb Y, Kelly SE, Brown JK, Wilson JM, Karr TL, Hunter MS (2001) A newly discovered bacterium associated with parthenogenesis and a change in host selection behavior in parasitoid wasps. P Natl Acad Sci USA 98:12555-12560

Zchori-Fein E, Perlman SJ (2004) Distribution of the bacterial symbiont Cardinium in arthropods. Mol Ecol 13:2009-2016

Zhang JJ, Ren BZ, Yuan XH, Zang LS, Ruan CC, Sun GZ, Shao XW (2014) Effects of host-egg ages on host selection and suitability of four Chinese Trichogramma species, egg parasitoids of the rice striped stem borer, Chilo suppressalis. Biocontrol 59:159-166

Zhao C, Xia Y, Guo Y, Li M, Zhang B, Li D (2019) The study on diapause induction in Anastatus japonicus Ashmead. Chin J Biol Control 35:282-287

Publisher's Note Springer Nature remains neutral with regard to jurisdictional claims in published maps and institutional affiliations. 